\title{
Research Note \\ RESPONSE OF COLONY STRENGTH TO HONEY PRODUCTION: REGRESSION AND CORRELATION ANALYSIS
}

\author{
S. J. Bhusal ${ }^{1}$ and R. B. Thapa ${ }^{2}$ \\ ${ }^{1}$ Regional Agriculture Research Station, Tarahara, Sunsari, Nepal \\ ${ }^{2}$ Institute of Agriculture and Animal Sciences, Rampur, Chitwan, Nepal
}

\begin{abstract}
An experiment was conducted using Randomized Complete Block (RCB) design to find the effects of initial colony strength of Apis mellifera L. on honey production with four levels of initial populations: 4 frames $(9,800), 6$ frames $(14,700), 8$ frames $(19,600)$ and 10 frames $(24,500)$ of adult honeybees per colony replicating 5 times during litchi flowering season (February to April, 2003) in Chitwan. This study revealed the exponential increase in honey production $\left\{\mathrm{Y}=4.22-0.7325 \mathrm{X}+0.09625 \mathrm{X}^{2}(4 \leq \mathrm{X} \leq 10\right.$ comb covered by bees per colony) and $\mathrm{Y}=4.22-0.000299 \mathrm{X}+0.000000016 \mathrm{X}^{2}(9,800 \leq \mathrm{X} \leq 24,500$ honeybees per colony), $\mathrm{n}=4$ \} producing 2.32, 1.59 and 1.18 times more honey from initially 10-, 8- and 6-frame colonies as compared to the honey production of $2.82 \mathrm{~kg} /$ colony from 4 -frame colonies. There was significantly positive linear correlation among colony attributes like colony strength, brood rearing, comb building, foraging activity and honey production.
\end{abstract}

Key words: Apis mellifera., honey bee population, colony attributes

\section{INTRODUCTION}

Modern beekeeping was initiated 15 years ago (Entomology Division, 1998; Shivakoti and Bista, 2000) introducing moveable frame hives to rear Apis cerana F. (Kafle, 1992). However, beekeeping with improved and imported crossbreed honeybee, Apis mellifera L. started since 1993-1995 (Entomology Division, 1999; Thapa and Pokhrel, 2001). Out of 127,501 bee colonies in the country, beekeepers follow improved management practices for only 17,744 A. cerana, and more than 7,456 A. mellifera colonies. Average annual honey yield is only $4.15 \mathrm{~kg}$ per colony (HMG/N, 2002).

Beekeeping can be started even with limited resources giving income and supplying nutrition (ICIMOD, 1999). In the context of worsening distribution of income over time (Koirala and Thapa, 1997), honey production through beekeeping could be a useful avenue improving rural economy (Baptist and Punchihewa, 1983). Nepal Agricultural Perspective Plan (APP) has recognized beekeeping as high value income generating enterprise (APROSC and JMA, 1995). Beekeeping also provides pollination service to the high value (horticulture) crops to the range of $30 \%$ to as high as $3000 \%$ (Reddy, 1995) which worth about 143 times more than honey production (Mishra, 1998).

The imported crossbreed $A$. mellifera has been gaining popularity in the country for few years because of its higher productivity and convenience in to handling (Entomology Division, 1996). However, the average honey production of different Apis species is far below their production potential even in good honey follow season due to farmers' ignorance (Verma, 1990).

Therefore, increased hive products like honey, wax, propolis, pollen, venom as well as crop productivity through crop pollination, the prime objective of beekeeping industry, can be achieved by increasing bee strength (Kumar and Singh, 2000). Improved colony management techniques and high yielding race result in higher colony population and quality production. This study was conducted to find out the relationship of initial colony population on brood rearing and honey production.

\section{MATERIALS AND METHODS}

The experiment was conducted during litchi flowering season (February to April, 2003) at Bharatpur, Chitwan valley ( $350 \mathrm{~m}$ asl) in 5 replicated Randomized Complete Block (RCB) design with four initial population levels of Apis mellifera L. colonies: 4 frames (9,800), 6 frames (14,700), 8 frames $(19,600)$ and 10 frames $(24,500)$ 
of adult honeybees per colony. Adult honeybees in each frame were maintained as follows:

Weight of bees per frame ()$=W_{1}-W_{2}$

No. of bees per frame $=\frac{x}{10} \times W$

Where, $\mathrm{W}_{1}=$ Weight of brood frame with adult bees.

$$
\begin{aligned}
\mathrm{W}_{2} & =\text { Weight of brood frame without adult bees. } \\
x & =\text { No. of adult bees per } 10 \mathrm{~g} \\
& =86 \pm 7.21 \text { (average } \pm \text { standard deviation) }
\end{aligned}
$$

Routine inspection of the colony was followed with common management practices of improved technology with the provision of safe water, stimulating feeding, use of comb foundation and supers, removal of descended and spare combs, swarming control, mite control, etc. in all the colonies.

Total brood (eggs, larvae and sealed brood) area, comb building and foraging activity in each colony was measured in each side of all combs at 21 days interval from the beginning of experiment up to the last shower of litchi bloom. Brood rearing area in each side of combs was converted to number of brood cells using readymade brood measuring table developed by Prof. J. Woyke (Pokhrel, 2001). Total number of cells per colony was calculated it is equivalent to the sum of the number of cells in each side of all combs.

Honey was harvested on April in the morning and evening hours of a sunny day leaving $1-2$ combs with honey in each colony by using a centrifugal honey extractor.

Analysis of variance (ANOVA), repeated ANOVA, analysis of covariance (ANOCOVA) and correlation analysis were performed by using computer software MSTATC to analyze significant difference among treatments. Treatment means were compared by Duncan's Multiple Range Test (DMRT) at 5\% level of significance $(\mathrm{p}<0.05)$. Regression among various quantitative attributes of beekeeping practices were analyzed by using computer software MINITAB for windows and a polynomial quadratic regression model was developed.

\section{RESULTS AND DISCUSSION}

The analysis of variance clearly indicated that honey production was significantly $(\mathrm{p}<0.0001)$ higher in strong colonies. Analysis of covariance (ANOCOVA) also was significant $(\mathrm{p}<0.01)$ after adjusting with initial amount of syrup honey storage as a covariate since the initial storage of syrup honey influenced the final production of honey.

The honey production showed an increasing trend with the increased initial population (Table 1). The trend was similar in both adjusted and unadjusted values. The honey production was adjusted with the hypothesis that initial amount of syrup honey storage might affect the production of honey, and therefore, honey production was adjusted with the initial amount of syrup honey storage as a covariate. The adjusted values give the actual increase of honey production due to the higher initial population in a colony.

Table 1. Mean number $( \pm \mathrm{SEm})$ of out-going and in-coming foragers, comb building and honey production with different levels of population during litchi flowering season, Chitwan, 2003

\begin{tabular}{|lcc|}
\hline \multirow{2}{*}{ Initial population } & \multicolumn{2}{c|}{ Honey production (kg/colony) } \\
\cline { 2 - 3 } & Unadjusted & Adjusted $\dagger$ \\
\hline frames & $2.90 \pm 0.30 \mathrm{c}$ & $2.82 \mathrm{c}$ \\
frames & $3.40 \pm 0.42 \mathrm{c}$ & $3.32 \mathrm{bc}$ \\
frames & $4.48 \pm 0.24 \mathrm{~b}$ & $4.49 \mathrm{~b}$ \\
frames & $6.42 \pm 0.81 \mathrm{a}$ & $6.53 \mathrm{a}$ \\
LSDp $<0.05$ & 15.60 & 16.20 \\
SEm \pm & 0.922 & 1.476 \\
\hline
\end{tabular}

Figures followed by same letters within the columns are not significant by DMRT, † - Means adjusted by Analysis of Covariance (ANOCOVA) analyzing with initial amount of syrup honey storage as a covariate 
The honey production was 1.18 times higher in 6 frame (14,700 bees) colonies ( $3.32 \mathrm{~kg} /$ colony) than that of 4 frame ( 9,800 bees) colonies ( $2.82 \mathrm{~kg} /$ colony); it was 1.35 and 1.59 times higher in 8 frame (19,600 bees) colonies $(4.49 \mathrm{~kg} /$ colony) than 6 and 4 frame colonies; similarly, it was 1.45, 1.97 and 2.32 times higher in 10 frame (24,500 bees) colonies $(6.53 \mathrm{~kg} /$ colony) than that of initially 8,6 and 4 frame colonies, respectively. Higher rate of honey production in larger and stronger colonies is due to the higher proportion of older bees as foragers producing one and half times more honey from one colony of $A$. mellifera with 60,000 worker bees than four colonies each with 15,000 worker bees (Verma, 1992).

The regression lines for bee population and honey production are presented in Figures 1, 2. The regression line of adjusted honey yield as dependent variable on initial bee population level fitted in quadratic regression model. The polynomial regression analysis for honey yield was $\mathrm{Y}=4.22-0.7325 \mathrm{X}+0.09625 \mathrm{X}^{2}(4 \leq \mathrm{X} \leq 10$ comb covered by bees per colony, $\mathrm{n}=4$ ) with $\mathrm{R}^{2}$ (coefficient of determinants) value $=1.00$ where $\mathrm{Y}$ is the honey production and $\mathrm{X}$ is the initial comb covered by honeybees per colony (Figure 1). While the polynomial regression analysis for honey yield was $\mathrm{Y}=4.22-0.000299 \mathrm{X}+0.000000016$ $X^{2}(9,800 \leq X \leq 24,500$ honeybees per colony, $n=4)$ with $R^{2}$ (coefficient of determinants) value $=1.00$ where $\mathrm{Y}$ is the honey production and $\mathrm{X}$ is the initial number of honeybees per colony (Figure 2). This quadratic regression model indicates the exponential growth in honey production with the initial colony strength. The $\mathrm{R}^{2}$ (coefficient of determinants $=1.00$ ) value proved the best fitted model. Such increase in honey production only in 9 weeks (one floral season) due to the colony strength suggested practicing beekeeping with adequate colony population throughout the honey flow season to make higher profit reducing cost of production.

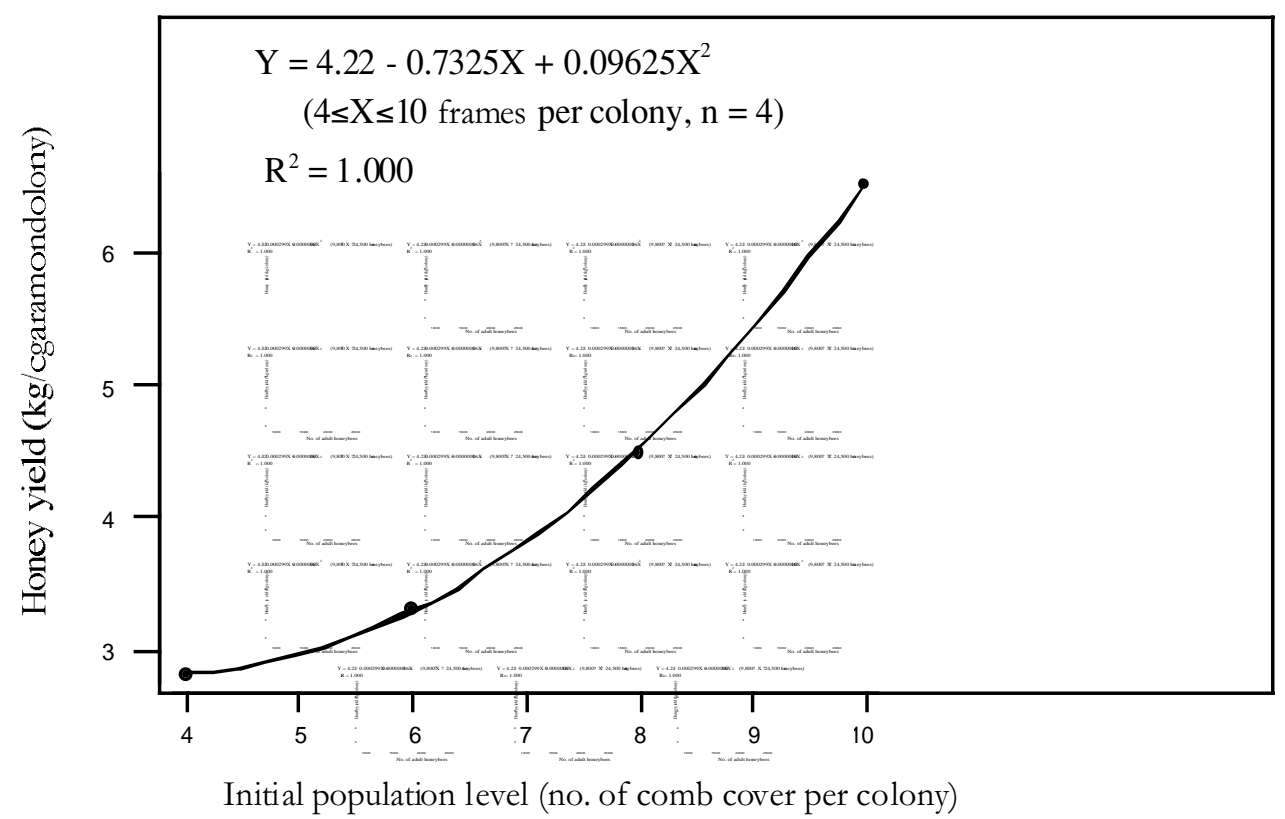

Figure 1. Regression line of honey yield by initial population level (initial number of frames covered by honeybees per colony) of $A$. mellifera

This result is almost similar to established productivity of $A$. mellifera even in this short period of litchi flowering season under Chitwan condition, though established productivity was $2 \times 1.36,3 \times 1.48$ and $1 \times 4 \times$ 1.54 times more yield from the colony population of 30,000, 45,000 and 60,000 bees than 15,000 bees in a colony (Jean-Prost and Medori, 1994) for the extended period of annual honey flow season.

The colony strength is directly proportional to brood rearing since strong colony always reared more broods (23857) in the colony. Higher number of worker bees can feed and care more broods. Lindauer (Gary, 1975) calculated that 2,785 bees involved in caring for one larva from egg stage to capping of the cell spending 10 hours, 16 minutes, and 8 seconds during this period.

The correlation among different attributes is presented in Table 2 . There was significant positive linear correlation among the attributes and colony performance. Foraging activity is another behavior of honeybees which was remarkably increased with the increment of brood in the hive and highly correlated with the colony 
strength and honey production. The beekeeping attributes were positively and significantly correlated. Pokhrel (2001) also found similar correlation among all parameters.

Table 2. Simple linear correlation coefficients among different attributes of A. mellifera colony, Chitwan, 2003

\begin{tabular}{|lccccc|}
\hline Colony attributes & Comb building & Brood rearing & Out-going bees & In-coming bees & Honey yield \\
\hline Colony strength & $0.987^{* *}$ & $0.991^{* *}$ & $0.999^{* *}$ & $0.994^{* *}$ & $0.963^{*}$ \\
Comb building & - & $0.955^{*}$ & $0.992^{* *}$ & $0.998^{* *}$ & $0.994^{* *}$ \\
Brood rearing & - & - & $0.983^{* *}$ & $0.977^{* *}$ & $0.918^{*}$ \\
Out-going bees & - & - & - & $0.988^{* *}$ & $0.973^{* *}$ \\
In-coming bees & - & - & - & - & $0.969^{*}$ \\
\hline
\end{tabular}

$*$ and $* *$, Significant at $(\mathrm{p}<0.05)$ and $(\mathrm{p}<0.01)$ probability levels

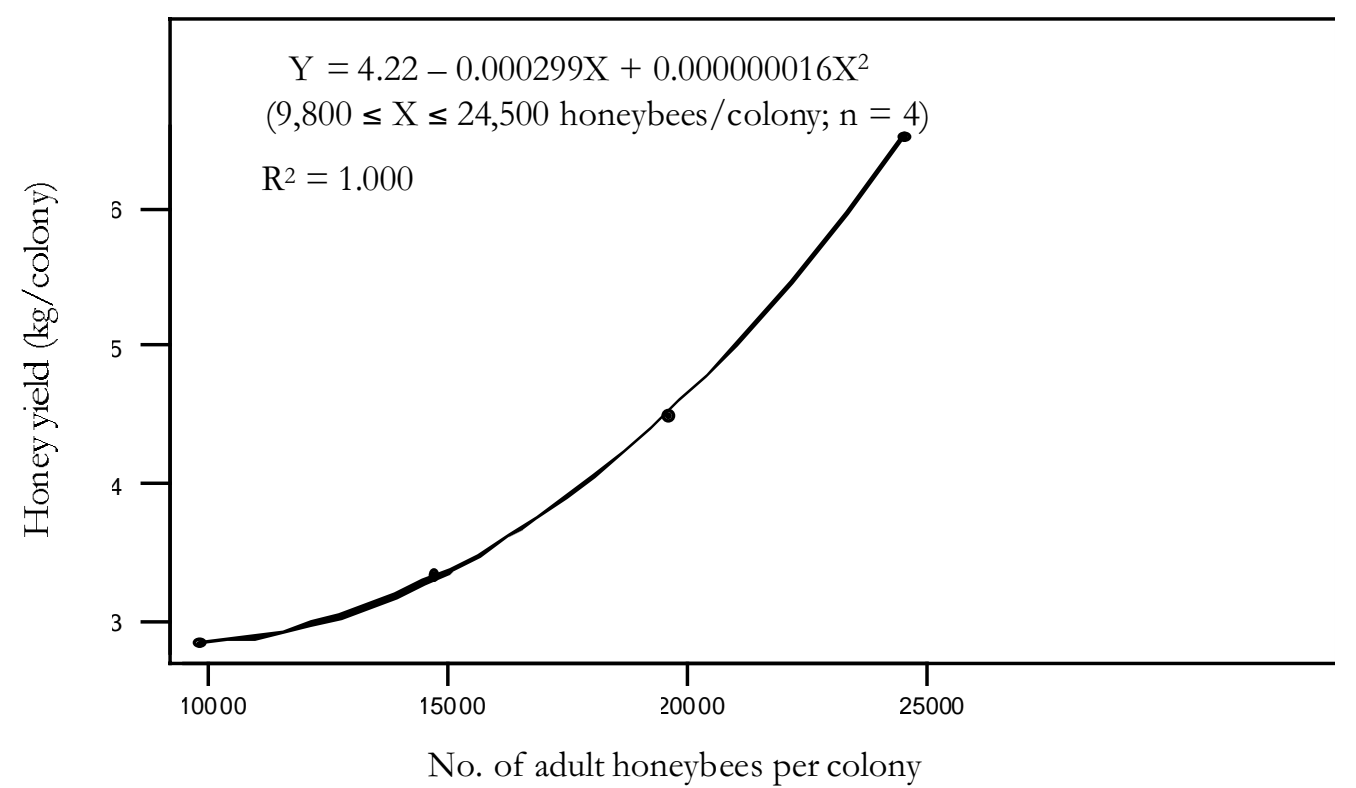

Figure 2. Regression line of honey yield by initial population level (initial number of honeybees per colony) of $A$. mellifera

\section{CONCLUSIONS}

Initial colony strength of honeybee is the most important component for successful beekeeping enterprise development. Colony strength is directly proportional to the rearing and foraging activity thereby increased comb building, pollen and nectar collection, their storage as bee bread and syrup honey resulting in the exponentially increased honey production even in a short period (February to April) of 9 weeks. Therefore, it is necessary to maintain colony strength to obtain greater yield and benefits from the enterprise during honey flow season.

\section{REFERENCES CITED}

APROSC and JMA. 1995. Agriculture perspective plan (APP). Agricultural Projects Services Centre, Kathmandu and John Mellor Associates, Inc., Washington D. C. 337 p.

Baptist, B. A. and R. K. W. Punchihewa. 1983. A Preliminary Analysis of the principal factors which will affect apiary honey production in Sri Lanka. In: K. N. Mehrotra, M. G. Jotwani, T. P. Sriharan, B. Subrahmanyam, P. J. Rao, D. S. Bisht and M. Naim (eds.). Second International Conference on Apiculture in Tropical Climate. Indian Agricultural Research Institute, New Delhi, India. pp. 87-99.

Entomology Division. 1996. Annual report (1995 - 1996). Nepal Agriculture Research Council, Khumaltar, Lalitpur, Nepal.

Entomology Division. 1998. Annual technical report (1997-1998). Nepal Agriculture Research Council, Khumaltar, Lalitpur, Nepal. 59 p. 
Entomology Division. 1999. Annual technical report (1998-1999). Nepal Agriculture Research Council, Khumaltar, Lalitpur, Nepal. 64 p.

Gary, N. E. 1975. Activities and behaviour of honey bees. In: The Hive and Honey Bee (Revised Edition). Dadant and Sons Inc., USA. pp. 185-265.

HMG/N. 2002. Annual progress and statistical book (2001 - 2002) (in Nepali). Bee Development Section, Godawari, Nepal. 47 p.

ICIMOD. 1999. Indigenous honeybees of the Himalayas: A community based approach to conserving biodiversity and increasing farm productivity. ICIMOD/AUSTRO Project Program. International Centre for Integrated Mountain Development, Kathmandu, Nepal.

Jean-Prost, P. and P. Medori. 1994. Apiculture: Know the bee, manage the apiary. Oxford and IBH Publishing Co., Pvt. Ltd., New Delhi, India. 667 p.

Kafle, G. P. 1992. Salient features of beekeeping in Nepal. pp. 155-162.. In: L. R. Verma (ed.) Honeybees in Mountain Agriculture. Proceedings of International Expert Meeting on Beekeeping Development in the Hindu Kush-Himalayan Region, Kathmandu, Nepal, June 21-23, 1989. Oxford and IBH Publishing Co., Pvt. Ltd., New Delhi, India.

Koirala, G. P. and G. B. Thapa. 1997. Food security challenges: Where does Nepal stand? HMG/N, MOA/ Winrock International, Kathmandu, Nepal. 41 p.

Kumar, Y. and M. Singh. 2000. Effect of colony strength and stimulant sugar- feeding on Apis mellifera. In: M. Matsuka, L. R. Verma, S. Wongsiri, K. K. Shrestha and U. Partap (eds.) Asian Bees and Beekeeping: Progress of Research and Development. Proceedings of Fourth Asian Apicultural Association International Conference, Kathmandu, 23-28 March 1998. Oxford and IBH Publishing Co., Pvt. Ltd., New Delhi, India. pp. 102-103.

Mishra, R. C. 1998. Perspectives in Indian apiculture. Agro Botanica, HS Offset Printers, New Delhi, India.

Pokhrel, S. 2001. Impact of supplement diets on brood and honey production of cross breed honeybee, Apis mellifera L. M. Sc. Thesis. Tribhuvan University, IAAS, Rampur, Chitwan, Nepal. 103 p.

Reddy, C. C. 1995. Management practices and migratory beekeeping. In: P. G. Kevan (ed.) The Asiatic Hive Bee: Apiculture, Biology and Role in Sustainable Development in Tropical and Subtropical Asia. Enviroquest Ltd., Canada. pp. 209-215.

Shivakoti, G. P. and S. Bista. 2000. Major constraints in the performance of Apis mellifera and Apis cerana under Khumaltar Conditions. In: M. Matsuka, L. R. Verma, S. Wongsiri, K. K. Shrestha and U. Partap (eds.). Asian Bees and Beekeeping: Progress of Research and Development. Proceedings of Fourth Asian Apicultural Association International Conference, Kathmandu, 23-28 March 1998. Oxford and IBH Publishing Co., Pvt. Ltd., New Delhi, India. pp. 29-32.

Thapa, R. B. and S. Pokhrel. 2001. Supplement diets for managing crossbreed Honeybee during off-season. J. Inst. Agric. Anim. Sci. 21-22: 179-186.

Verma, L. R. 1990. Beekeeping in Integrated Mountain Development: Economic and Scientific Perspectives. Oxford \& IBH Publishing Co., Pvt. Ltd., New Delhi, India. 274 p.

Verma, L. R. 1992. Beekeeping and pollination ecology of mountain crops. In: L. R. Verma (ed.) Honeybees in Mountain Agriculture. Proceedings of International Export Meeting on Beekeeping Development in the Hindu Kush-Himalayan Region, Kathmandu, Nepal, $21-23$ June 1989. Oxford and IBH Publishing Co., Pvt. Ltd., New Delhi, India. pp. 69-89. 